\title{
Informasi Diagnostik Pemeriksaan Appendikografi Oral Dan USG Dalam Menegakkan Diagnosis Appendisitis
}

\author{
Agustina Dwi Prastanti ${ }^{1}$, Darmini ${ }^{2}$, Andrey Nino Kurniawan ${ }^{3}$ \\ ${ }^{1,2,3}$ Poltekkes Kemenkes semarang, Indonesia \\ Corresponding author: Agustina Dwi Prastanti \\ e-mail : agustina.jtrr@poltekkes-smg.ac.id
}

Received: January $30^{\text {th }}, 2021$; Revised: January $31^{\text {st }}, 2021$; Accepted: February $1^{\text {st }}, 2021$

\begin{abstract}
Background: Patients with suspected appendicitis are always asked by the sending doctor (Pediatric Surgeon) to ask for an oral appendicography examination without seeking other investigations such as ultrasound or CT scan. Whereas in the oral appendicography examination, false negative often occurs so that the patient is exposed to radiation several times until the barium reaches the caecum area and no more barium is still in the small intestine. Compared to the oral appendicography examination, ultrasound examination is easier in patient preparation, cheaper in terms of cost and more safety against the dangers of $\mathrm{X}$-ray radiation.

Methods: This research is a descriptive analytic study conducted with a cross sectional approach. The study was conducted by providing interventions for ultrasound examination before carrying out an oral appendicography examination. Ultrasound examination of the appendix is an examination using ultrasound waves with a frequency of $5-7.5 \mathrm{MHz}$ or $2-4 \mathrm{MHz}$ to diagnose appendicitis. Oral appendicography examination is a radiological examination to confirm the diagnosis of appendicitis using 100 grams of barium sulfate contrast medium diluted to a volume of $200 \mathrm{ml}$ that is administered orally.

Results: Diagnostic information obtained on oral appendicography examination of suspected appendicitis in radiology department Roemani Hospital, among others, can show the presence of calcification and the length of the appendix organs can be measured. Diagnostic information obtained on ultrasound examination of suspected appendicitis, among others, can show the presence of debris (pus), can evaluate the thickness of the intestinal wall and its vascularity.

Conclusion: Ultrasound examination for suspected appendicitis is the first choice in diagnosing appendicitis than oral appendicography because it can be done in a faster, safer, more convenient and non-invasive manner and the cost of ultrasound is cheaper than oral appendicography.
\end{abstract}

Keywords : Appendicitis; oral appendicography; ultrasound of the appendix

\section{Pendahuluan}

Pemeriksaan apendikografi oral pada pasien pediatrik di RS Roemani Muhammadiyah Semarang merupakan pemeriksaan yang sering dijumpai. Dalam waktu satu bulan terdapat kurang lebih 10 pasien pediatrik. Setiap pasien pediatrik dengan dugaan apendisitis selalu oleh dokter pengirim (Spesialis Bedah Anak) meminta pemeriksaan apendikografi oral tanpa mencari pemeriksaan penunjang yang lain seperti USG atau CT scan. Padahal pada pemeriksaan apendikografi oral sering terjadi false negative sehingga pasien terkena radiasi beberapa kali sampai barium mencapai area caecum dan tidak ada lagi barium yang masih berada di usus halus. Dibandingkan dengan pemeriksaan Apendikografi Oral, pemeriksaan USG lebih mudah dalam persiapan pasien, lebih murah dari segi biaya dan lebih safety terhadap bahaya radiasi sinar X.

Penegakan diagnosis apendisitis dapat dilakukan melalui pemeriksaan radiologi, yang salah satunya dengan radiografi konvensional yaitu pemeriksaan apendikografi oral (Hasya, 2012). Pemeriksaan radiologi ini akan berperan bila masih terdapat keraguan dalam diagnosisnya atau diagnosis yang masih bersifat suspect, karena jika sudah jelas bahwa seseorang menderita radang apendiks, maka tidak memerlukan pemeriksaan radiologi lagi, dan akan langsung dilakukan apendiktomi (Avanesov et al., 2018).

Apendikografi atau appendicogram merupakan salah satu jenis pemeriksaan radiografi yang umum digunakan di Indonesia sebagai pemeriksaan penunjang dalam menegakkan diagnosis 
apendisitis. Pemeriksaan ini menggunakan $\mathrm{BaSO}_{4}$ (barium sulfat) yang diencerkan dengan air menjadi suspensi barium dan dimasukkan secara oral. Hasil dari pemeriksaan ini dapat menggambarkan anatomi fisiologis dari apendiks dan kelainan pada apendiks berupa sumbatan pada pangkal apendiks (Baresti \& Rahmanto, 2017).

Hasil pemeriksaan apendikografi dibagi menjadi tiga, yakni yang pertama adalah filling atau positive appendicogram yang berarti keseluruhan lumen apendiks terisi penuh oleh barium sulfat. Gambaran ini menandakan bahwa tidak ada obstruksi pada pangkal apendiks sehingga suspensi barium sulfat yang diminum oleh pasien dapat mengisi lumen apendiks hingga penuh. Kedua partial filling yang berarti suspensi barium sulfat hanya mengisi sebagian lumen apendiks dan tidak merata. Ketiga non filling atau negative appendicogram yang berarti barium sulfat tidak dapat mengisi lumen apendiks. Ada beberapa kemungkinan penyebab dari gambaran negatif appendicogram yakni adanya obstruksi pada pangkal apendiks (dapat berupa inflamasi) yang mengindikasikan apendisitis atau suspensi barium sulfat belum mencapai apendiks karena perhitungan waktu yang tidak tepat (false negative appendicogram)(Majdawati, 2007).

Pemeriksaan appendicogram dilaporkan memiliki tingkat sensitivitas dan spesifisitas yang tinggi, sebesar 83 dan 96 persen. Walau demikian, pemeriksaan ini memiliki banyak keterbatasan yang mempengaruhi akurasinya, seperti kesulitan untuk mendiagnosa apendisitis distal, tingkat nonvisualisasi yang tinggi $(23 \%)$ pada orang normal/ Hasil positif pada appendicogram juga bukan merupakan hasil yang spesifik pada apendisitis dan bisa ditemukan pada kondisi lain. Hal ini ditambah dengan efek samping dan risiko yaitu reaksi alergi terhadap barium, obstruksi traktus gastrointestinal, inflamasi jaringan sekitar kolon, perforasi kolon dan peningkatan risiko operasi apendektomi. Dengan berbagai risiko pemeriksaan yang cukup tinggi membuat pemeriksaan ini sehingga tidak lagi digunakan di negara maju dan digantikan dengan ultrasonografi untuk diagnosis lini pertama (Hasya, 2012).

Pemeriksaan apendikografi oral di RS Roemani Muhammadiyah Semarang merupakan pemeriksaan yang masih sering dijumpai. Setiap pasien dengan dugaan apendisitis selalu oleh dokter pengirim (Spesialis Bedah Anak) meminta pemeriksaan apendikografi oral tanpa mencari pemeriksaan penunjang yang lain seperti USG atau CT scan. Padahal pada pemeriksaan apendikografi oral sering terjadi false negative sehingga pasien terkena radiasi beberapa kali sampai barium mencapai area caecum dan tidak ada lagi barium yang masih berada di usus halus. Dibandingkan dengan pemeriksaan Apendikografi Oral, pemeriksaan USG lebih mudah dalam persiapan pasien, lebih murah dari segi biaya dan lebih safety terhadap bahaya radiasi sinar X (Majdawati, 2007).

\section{Metode}

Jenis penelitian yang dilakukan di RS Roemani Muhammadiyah Semarang adalah penelitian deskriptif analitik dengan pendekatan cross sectional.

Peneltian dilakukan dengan menetapkan populasi dalam penelitian ini adalah seluruh pemeriksaan appendikografi oral. Sedangkan sampel yang digunakan dalam penelitian ini adalah pasien dengan permintaan foto appendikografi oral yang diberikan intervensi untuk pemeriksaan USG terlebih dahulu.

Pemeriksaan appendikografi oral merupakan pemeriksaan secara radiologis untuk menegakkan diagnosis appendisitis dengan menggunakan media kontras barium sulfat 100 gram yang diencerkan mencapai volume $200 \mathrm{ml}$ yang dimasukkan secara oral (Bontrager \& Lampignano, 2014). Sedangkan pemeriksaan dengan USG merupakan pemeriksaan dengan menggunakan gelombang ultrasonografi dengan frekuensi 5-7,5 MHz atau 2-4 MHz untuk menegakkan diagnosis appendisitis.

Sampel yang digunakan merupakan bagian dari populasi yang memenuhi kriteria inklusi yaitu pasien dengan permintaan pemeriksaan apendikografi. Analisis data dalam penelitian ini menggunakan analisis data univariat yaitu menjelaskan secara deskriptif karakteristik penderita meliputi usia, hasil pemeriksaan USG dan apendikografi oral.

\section{Hasil dan Pemhasan}

Penelitian tentang informasi diagnostik pemeriksaan appendikografi oral dan USG dalam menegakkan diagnosis appendisitis di RS Roemani Muhammadiyah ini terdapat 5 (lima) sampel pasien dengan deskripsi sampel 2 (dua) laki-laki dengan usia 12 tahun dan 15 tahun. Dan 3 (tiga) pasien perempuan dengan usia 44 tahun, 14 tahun dan 34 tahun. Kelima sampel ini dilakukan pemeriksaan USG dan Apendikografi Oral. Pemeriksaan USG dilakukan sebelum pemeriksaan apendikografi oral. Semua sampel adalah dengan klinis suspect apendisitis. 


\section{Hasil USG dan Apendikografi Oral}

Hasil USG An.P 12 th dengan hasil bacaan: Tak tampak appendicitisTak tampak kelainan pada organ intra abdomen secara pemeriksaan USG (b)Hasil App Oral An.P 12th: Tak tampak barium mengisi appendix; mendukung diagnosa appendicitis, jika physical findings didaerah appendix mendukung.

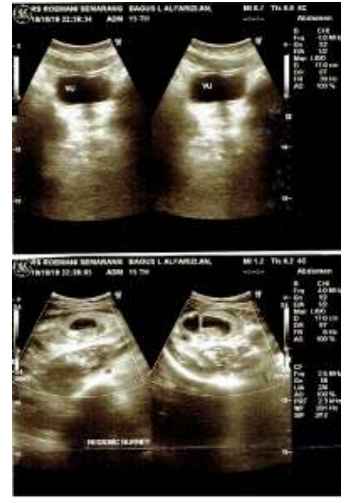

(a)

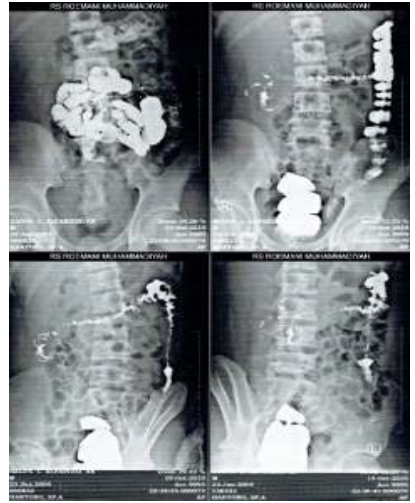

(b)
Gambar 2. (a)Hasil USG An.P 15 th dengan hasil bacaan: Regio Mc Burney tampak gambaran massa tubuler dengan penebalan dinding dan debris didalamnya dengan pemeriksaan color doppler tampak peningkatan vaskuler suspek gambaran apendicitis dengan abses; Tak tampak kelainan pada organ intra abdomen lainnya secara pemeriksaan USG (b) Hasil App Oral An.P 15 th:Kontras masuk sudah mengisi colon ascendens proksimal, colon transversum, colon descendens, colon sigmoid, rectum; Apendiks tidak terisi kontras; Kesan: apendiks sulit dievaluasi ec tak terisi kontras; Konfirmasi USG: suspek gambaran apendiksitis dengan abses.

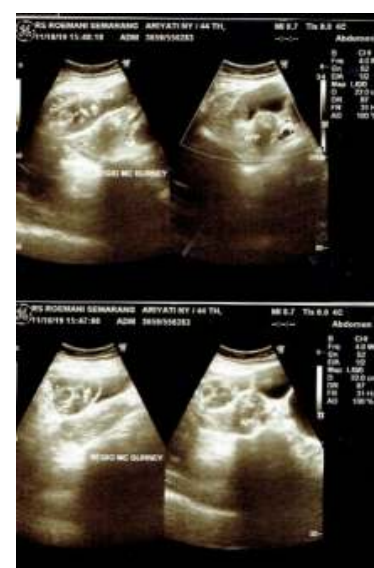

(a)

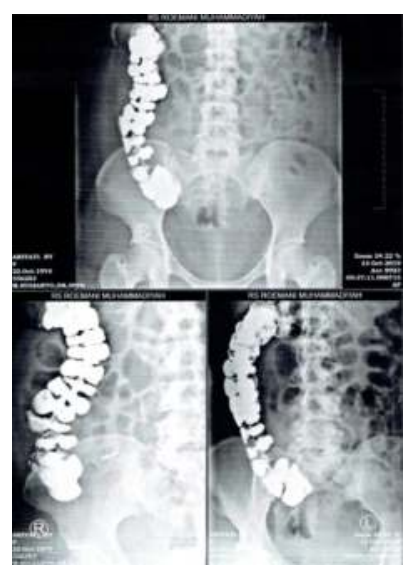

(b)
Gambar 3. (a) Hasil USG Ny.A 44th: Regio Mc Burney tampak gambaran lesi tubuler dengan debris didalamnya disertai dilatasi usus dengan pemeriksaan color doppler tampak peningkatan vaskuler suspek apendicitis dengan dilatasi usus dd massa kista ovarii sinistra ukuran 3,68 x 2,54 cm; Tak tampak kelainan pada organ intra abdomen lainnya secara pemeriksaan USG. (b) Hasil App Oral Ny.A 44th: Kontras setelah 6-8 jam sudah mengisi caecum, pasase kontras lancar. Tampak apendiks terisi kontras, ada filling defect dan bentuk spastik; Kesan : Apendicitis kronis.
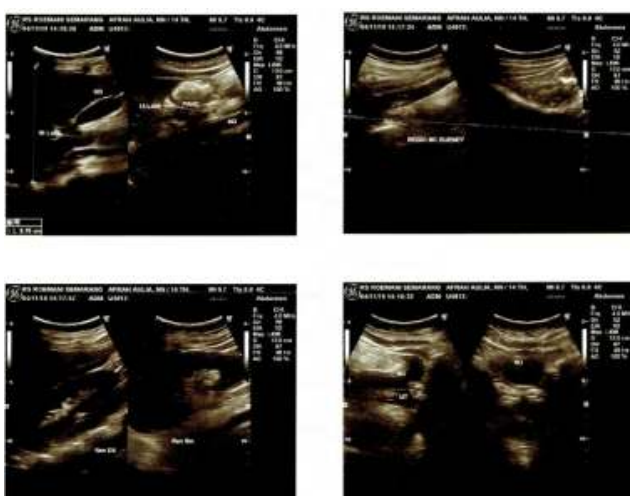

(a)

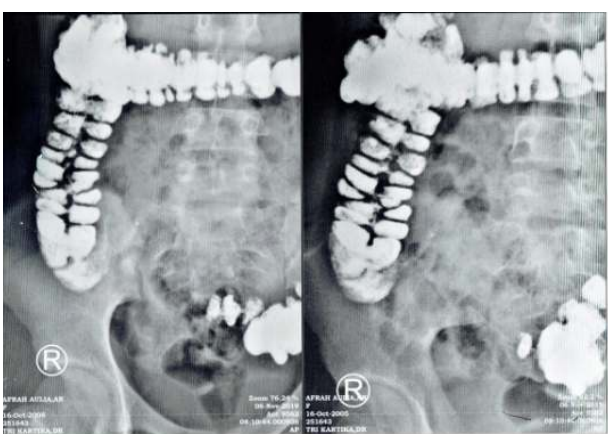

(b)

Gambar 4. (a) Hasil USG An. Au 14th: Regio $M c$ Burney: tak tampak gambaran penebalan dinding tubuler blind end tube maupun massa; Kesan: Tak tampak appendicitis maupun adneksitis; Tak tampak kelainan pada organ intraabdomen secara pemeriksaan USG. (b) Hasil App Oral An. Au 14th: Kontras sudah mengisi caecum, apendiks, colon ascendens, colon transversum, colon descendens; Appendiks terisi kontras dinding iregular dengan kalsifikasi dan penyempitan. Kesan: Ireguler dinding apendiks dengan kalsifikasi dan penyempitan suspek apendisitis kronik.

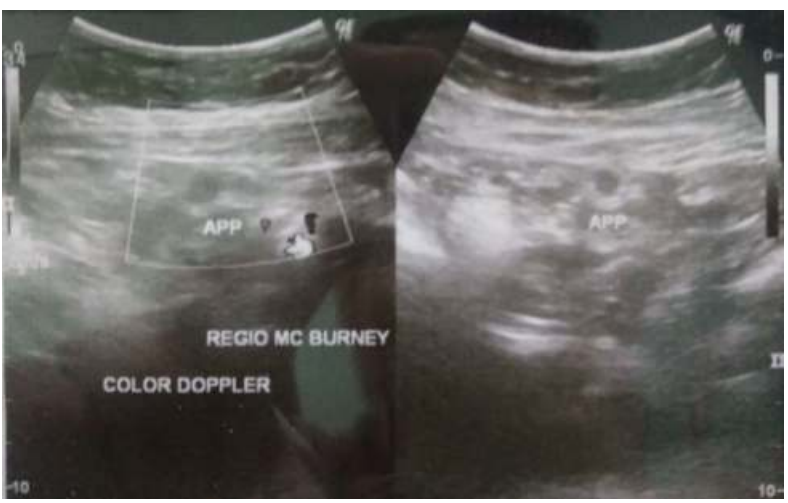

(a) 


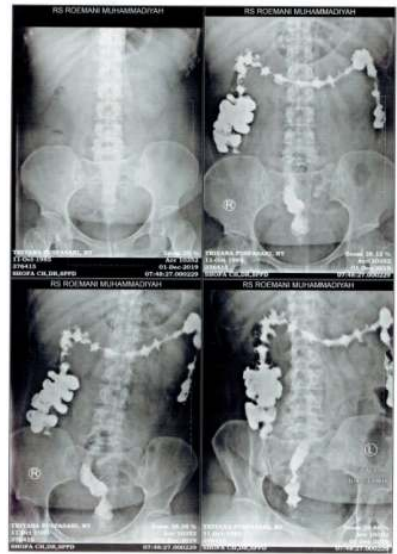

(b)

Gambar 5. (a)Hasil USG Ny.T 34th: Regio Mc Burney: gambaran penebalan tubuler blind end tube disertai debris didalamnya dengan pemeriksaan color doppler tampak peningkatan vaskuler. Kesan:Regio Mc Burney gambaran penebalan tubuler blind end tube disertai debris didalamnya dengan pemeriksaan color doppler tampak peningkatan vaskuler suspek gambaran apendicitis. (b) Hasil App Oral Ny.T 34th: Appendix tak terisi barium, tetapi pada saat difoto, pasien sudah buang air besar (tak dapat menahan). Kesan:Barium tak tampak dalam appendix, masih mungkin karena appendicitis bila klinis mendukung, tapi dapat juga karena barium tak cukup lama dan tak cukup banyak dalam usus.

Penelitian tentang Informasi Diagnostik Pemeriksaan Appendikografi Oral dan USG dalam Menegakkan Diagnosis Appendisitis di RS Roemani Muhammadiyah Semarang menggunakan 5 sampel penelitian dimana untuk masing-masing sampel mendapat perlakuan USG abdomen sebelum dilakukan pemeriksaan apendikografi oral. Pemeriksaan apendikografi oral dilakukan dengan meminumkan media kontras barium kemudian pemeriksaan dilakukan dengan jangka waktu 7-8 jam setelah pasien meminum barium dengan harapan media kontras mencapai daerah sekum.

\section{Informasi diagnostik pemeriksaan apendikografi oral suspek appendisitis}

Informasi diagnostik yang didapat pada pemeriksaan apendikografi oral suspek apendisitis di RS Roemani Muhammadiyah Semarang antara lain dapat memperlihatkan adanya kalsifikasi dan panjang organ appendiks dapat terukur. Sesuai hasil bacaan Radiolog dari kelima sampel dapat dievaluasi area appendiks melalui media kontras barium yang mengisi usus. Dari kelima sampel pasien terdapat 3(tiga) pasien yang dinyatakan mendukung suspek appendisitis adalah dengan barium yang tidak mengisi appendiks tetapi tetap harus didukung dengan pemeriksaan fisik. Sedangkan 2(dua) pasien juga dinyatakan appendisitis meskipun barium mengisi appendiks tetapi dengan adanya tambahan informasi berupa filling defect, spastik dan dinding ireguler.

Pemeriksaan appendikografi oral yang merupakan bagian dari pemeriksaan abdominal $\mathrm{x}$ ray yang kemungkinan dapat memperlihatkan: fluid level pada sekum dan ileum terminal, ileus dengan gas didalam sekum, peningkatan densitas soft tissue pada kuadran kanan bawah, gambaran bluring pada bagian iliaka kanan dengan adanya garis radiolusen antara lemak peritoneum dan abdominal transversus, fekalit pada fosa iliaka kanan, udara yang mengisi appendiks, gas intraperitoneal, deformitas bayangan gas sekum yang terjadi karena massa yang mengalami inflamasi karena letak yang berdekatan, bayangan blur pada psoas sisi kanan. Akan tetapi 68\% interpretasi penegakan diagnosis appendisitis tidak spesifik dikarenakan banyak dari kasus obstruksi tidak terjawab pada pemeriksaan ini. Appendisitis memiliki tanda-tanda radiografi yang non-spesifik. Hal ini diperkuat dari beberapa penelitian bahwa hasil dari apendikografi oral memiliki dampak yang sangat kecil dalam pengambilan keputusan (Al-Khusheh et al., 2011).

Kelemahan pada pemeriksaan apendikografi oral yaitu tidak dapat mengevaluasi adanya debris (nanah), tidak dapat mengevaluasi ketebalan dinding usus dan vaskularisasinya, memerlukan waktu yang lama dalam prosedur pemeriksaannya dan pasien terkena paparan radiasi sinar-X berkalikali. Menurut Al-Khusheh et al. (2011), diagnosis appendisitis menggunakan $\mathrm{x}$-ray akan meningkatkan biaya perawatan kesehatan dan paparan radiasi yang tidak diperlukan untuk pasien. Oleh karenanya appendikografi oral hanya dilakukan jika sangat diperlukan saja dan sesuai dengan hasil pemeriksaan fisik.

\section{Informasi diagnostik pemeriksaan USG suspek appendisitis}

Informasi diagnostik yang didapat pada pemeriksaan USG suspek apendisitis antara lain dapat memperlihatkan adanya debris (nanah), dapat mengevaluasi ketebalan dinding usus dan vaskularisasinya. Sesuai hasil bacaan Radiolog dari kelima sampel dapat dievaluasi area appendiks melalui USG appendiks.

Terdapat 3(tiga) pasien yang dinyatakan mendukung suspek appendisitis adalah dengan adanya gambaran massa tubuler/ lesi tubuler, blind 
end tube, debris, penebalan dinding, dilatasi usus dan peningkatan vaskularisasi. Hal ini sesuai dengan apa yang dikemukakan oleh Rettenbacher et al. (2000) dan Gaitini (2011) bahwa kasus apendisitis dilakukan dengan USG secara transversal dan linear. Secara transversal dievaluasi kompresibilitasnya dan diameter lumen appendiks sementara secara linier dievaluasi adanya gambaran blind end tube dan penebalan dinding appendiks. Jika appendiks yang normal maka tidak terdapat gambaran blind end tube.

Kelemahan pada pemeriksaan USG pada suspek appendisitis yaitu tidak dapat mengevaluasi adanya kalsifikasi dan tidak dapat melakukan pengukuran panjang appendiks. Sesuai dengan Gaitini (2011) bahwa keuntungan pemeriksaan USG yaitu lebih nyaman untuk pasien, tidak bersifat invasif dan pasien tidak terkena paparan radiasi sinar- $X$ yang sangat merugikan terutama bagi anak-anak yang rentan terhadap radiasi sinar$\mathrm{X}$.

\section{Pemeriksaan yang Menjadi Pilihan Utama dalam Menegakkan Diagnosis Apendisitis}

Hasil penelitian yang didapat dari 5 (lima) sampel pasien suspek apendisitis yang dilakukan USG terlebih dahulu kemudian dilakukan apendikografi oral menyatakan 4 (empat) pasien dengan pemeriksaan USG mendukung diagnosis apendisitis. Sedangkan pada pemeriksaan apendikografi oral dari 5 (lima) sampel pasien yang memberi kesan apendisitis adalah 3 (tiga) orang. Dimana 2 (dua) orang pasien tidak dapat dievaluasi karena media kontras yang tidak mengisi appendiks dan dikembalikan pada pemeriksaan fisik. Sedangkan yang satu pasien tidak bisa dievaluasi dikarenakan media kontras tidak cukup berada lama dalam usus pasien karena pasien tidak dapat menahan BAB.

Berdasarkan paparan hasil penelitian dapat diambil kesimpulan pemeriksaan USG untuk suspek apendisitis menjadi pilihan yang pertama dalam mendiagnosis apendisitis daripada apendikografi oral dikarenakan dapat dilakukan dengan waktu yang lebih cepat, aman, nyaman dan tidak bersifat invasif serta biaya USG lebih murah daripada apendikografi oral. Lebih cepat karena pasien tidak perlu melakukan persiapan khusus dalam pemeriksaan USG. Aman karena pasien tidak terkena paparan radiasi sinar- $X$ yang tidak perlu, karena pada pasien apendikografi oral dapat menerima paparan radiasi berulang-ulang. Nyaman dan tidak invasif karena dengan USG pasien tidak perlu minum media kontras barium yang rasanya tidak enak. Karena pada beberapa kasus terdapat pasien yang kesulitan dalam menelan media kontras secara oral. Hal ini sesuai dengan Hasya (2012), pemeriksaan appendikografi oral memiliki banyak keterbatasan yang mempengaruhi akurasinya, seperti kesulitan untuk mendiagnosa apendisitis distal, tingkat nonvisualisasi yang tinggi (23\%) pada orang normal/ Hasil positif pada appendicogram juga bukan merupakan hasil yang spesifik pada apendisitis dan bisa ditemukan pada kondisi lain. Hal ini ditambah dengan efek samping dan risiko pemeriksaan yang cukup tinggi membuat pemeriksaan ini tidak lagi digunakan di negara maju dan digantikan dengan ultrasonografi untuk diagnosis lini pertama.

Keterbatasan penelitian ini yaitu pasien diharuskan menunggu kedatangan dokter Radiolog yang melakukan pemeriksaan USG sebelum dilakukannya pemeriksaan appendikografi oral. Hal ini dikarenakan SDM yang terbatas yaitu tidak terdapatnya petugas Sonografer. Sehingga hal ini mengakibatkan pelaksanaan pemeriksaan appendikografi oral menjadi tertunda. Sehingga waktu penelitian tidak cukup untuk mendapatkan sampel yang banyak.

\section{Simpulan}

Informasi diagnostik yang didapat pada pemeriksaan apendikografi oral suspek apendisitis yaitu dapat memperlihatkan adanya kalsifikasi dan panjang organ appendiks dapat terukur. Sedangkan informasi diagnostik yang didapat pada pemeriksaan USG suspek apendisitis yaitu dapat memperlihatkan adanya debris (nanah), dapat mengevaluasi ketebalan dinding usus dan vaskularisasinya.

Pemeriksaan USG untuk suspek apendisitis menjadi pilihan yang pertama dalam mendiagnosis apendisitis daripada apendikografi oral dikarenakan dapat dilakukan dengan waktu yang lebih cepat, aman, nyaman dan tidak bersifat invasif serta biaya USG lebih murah daripada apendikografi oral.

\section{Daftar Pustaka}

Al-Khusheh, M., Iqbal, S. J., Gupta, A., Asalieh, H., Khalifa, K., \& Habeeb, K. (2011). The Role of Abdominal X-Rays in The Investigation of Suspected Acute Appendicitis. Journal of Medicine and Medical Sciences, 2(11).

Avanesov, M., Wiese, N. J., Karul, M., Guerreiro, H., Keller, S., Busch, P., ... Yamamura, J. (2018). DiagnosticPrediction of Complicated Appendicitis by Combined Clinical and Radiological Appendicitis Severity Index (APSI). European 
Radiology, 28(9). https://doi.org/10.1007/s00330018-5339-9

Baresti, S. W., \& Rahmanto, T. (2017). Sistem Skoring Baru untuk Mendiagnosis Apendisistis Akut. MAJORITY, 6(3), 169-173. Retrieved from https://juke.kedokteran.unila.ac.id/index.php/majo rity/article/view/1130

Bontrager, K. L., \& Lampignano, J. P. (2014). Textbook of Radiographic Positioning and Related Anatomy (8th ed.). 8th ed. St. Louis, Mo: Elsevier/Mosby.

Gaitini, D. (2011). Imaging Acute Appendicitis: State of The Art. Journal of Clinical Imaging Science, 1(1). https://doi.org/10.4103/2156-7514.85778

Hasya, M. N. (2012). Reliabilitas Pemeriksaan Appendicogram dalam Penegakan Diagnosis Apendisitis di RSUD Dr. Pirngadi Medan Periode 2008-2011 (Universitas Sumatera Utara, Medan). Retrieved from http://repository.usu.ac.id/handle/123456789/3137 4

Majdawati, A. (2007). Peningkatan Visualisasi Appendix dengan Kombinasi Adjuvant Teknik Pemeriksaan Ultrasonografi pada Kasus Appendicitis. Mutiara Medika, 7(1), 58-71. https://doi.org/https://doi.org/10.18196/mmjkk.v7i $1 \% 20(\mathrm{~s}) .1686$

Rettenbacher, T., Hollerweger, A., Macheiner, P., Rettenbacher, L., Frass, R., Schneider, B., \& Gritzmann, N. (2000). Presence or Absence of Gas in The Appendix: Additional Criteria To Rule Out or Confirm Acute Appendicitis - Evaluation With US. Radiology, 214(1). https://doi.org/10.1148/radiology.214.1.r00ja2018 3

Sander, M. A. (2011). Apendisitis Akut: Bagaimana Seharusnya Dokter Umum dan Perawat Dapat Mengenali Tanda Dan Gejala Lebih Dini Penyakit Ini ? JURNAL KEPERAWATAN, 2(1), 15-20. Retrieved from https://doi.org/10.22219/jk.v2i1.479 